\title{
阪神・淡路大震災被災地における市街地変容と中高層マンションの実態 THE ACTUAL CONDITIONS OF THE CHANGES OF URBAN AREAS AND MID-TO HIGH-RISE APARTMENT HOUSES IN THE HANSHIN:AWAJI EARTHQUAKE DISASTER AREAS
}

\author{
徳尾野 徹*，杉山茂一** \\ Tetsu TOKUONO and Shigekazu SUGIYAMA
}

\begin{abstract}
The increasing apartment houses in the Hanshin-Awaji disaster areas exposed the problems in existing residential areas. We selected 4 distinctive districts to implement interview research, field investigations and analyses of materials or maps. First, we illustrated, through regulations and the processes of changing urban areas, the actual conditions of the periods when apartment houses are being built. We clarified the basic points on architectural planning in apartment houses as a next step. As a result, we demonstrated the realities of apartments after the earthquake, the problems on transient remedies and the differences according to site scales, provision systems.
\end{abstract}

Keywords : Changes of Urban Areas, Mid- to High-rise Apartments, Existent Residential Areas, Residential Environments, Laws and Regulations, Urban Policy Conferences 市街地変容, 中高層マンション, 既成住宅市街地, 住環境, 法規制, まちづくり協議会

\section{1. はじめに}

\section{1-1 研究の背量と目的}

1995 年に起きた阪神・淡路大震災の被災地のなかでも, 神戸市灘 区から西宮市にかけての地域は，低層建物を中心とした比較的良好 な住宅市街地として成熟段階にあった。即ち, 市街地化が完了した のち年数を経て, 初期の低層建物は更新時期を迎え, その一部は個 別にマンション化しつつあった。震災後, 都市計画事業等の復興事 業対象地以外では, 個別建設による中高層マンション化が急速に進 み, マンション紛争が多発した注11。これに対して行政や住民によ る様々な対応がなされてきたが，市街地住環境整備への寄与といっ た観点からみた市街地立地マンションの建築計画のあり方について は，多くの問題と課題が残されたままでいる注2)。

被災地における急速な中高層マンション化は市街地の変容を短 期間に凝縮したものであり，これに伴って，相隣関係，駐車場，景 観阻害などの問題が顕在化したとみなすことができる。このように とらえて, 本研究では, まず市街地変容過程との関係で被災地にお ける中高層マンション化の実態を概観し，そこでの問題点を明らか にする。

一方, 本研究は市街地立地マンションの建築計画のあり方を探る ものであるが，その内容は法規制と事業収支に左右されるところが
大きい。本研究では，西宮市と神戸市における被災地を調査対象に 選定し，法規制の違いによるマンション建築計画の違いを比較検討 する。また, 調査対象地におけるマンションの建築計画の内容を事 業主体別，供給方式別に比較して，事業の違いによるマンション建 築計画の相違をみる。

本研究は，以上の分析にもとづいて，市街地住環境整備に向けてより 有効なマンションに対する規制のあり方を探り,さらに開発事業者の主体 的取組みの誘導を検討することを目的とするものである。なお，本編で扱 うのは, 敷地規模, 建物高さ, 容積率等の建築計画にかかわる基本事項 であり,より詳細な内容は稿を改めて発表の予定である。

\section{1-2 研究の位置づけ}

阪神・淡路大震災被災地における復興を扱った研究, 市街地住環 境整備に対する規制・誘導に関する研究，市街地立地マンションの 計画内容を扱った研究など本研究に関連した研究は数多い。

阪神・淡路大震災被災地における市街地復興の問題を扱ったもの に, 平山他文2) や重村他文3) の研究がある。これらは, 既成住宅市 街地の再建プロセスと住宅ストックの変容の分析より, 住宅市街地 形成上の問題点を指摘している。

市街地住環境整備に対する規制・誘導に関しては, 酒井・土井文4), 岡・鳴海文5), 高見沢文6)，中西他文7) の研究がある。これらは，実

本論文の現地調查,ヒアリング調查は湖住宅䋓合研究財団の1999年度及び2001年度研究助成によって行った。

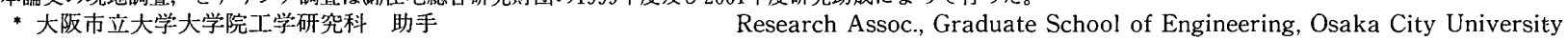

***大阪市立大学大学院工学研究科 教授.工博～Prof., Graduate School of Engineering, Osaka City University, Dr. Eng. 
際のあるいは仮想の市街地における法規制の運用や適用を分析する ことにより，その限界を示し，柔軟な法規制を志向している。 市街地立地マンションの計画内容を扱った研究としては, 佐々 木·花里文8)，鈴木·服部他文9)，井上他文10) の研究がある。計画内 容あるいは計画プロセスの分析により，多様化するニーズや外部空 間のあり方に関する新たな展開のための課題を提示している。

市街地住環境と中低層共同住宅の計画内容を扱った研究には小 浦・岡文 1 1) の研究がある。震災後の芦屋市市街地における多様な中 低層共同住宅化の実態を分析し, 今後の中低層住宅市街地における 住環境形成上の問題と課題を指摘している。

また高田・巽文12) は，大都市の典型と考えられる大阪市内に立地 する多様な分讓マンションを物的計画の視点から類型化して, 類型 ごとに特定の地区に集中する傾向があり，各地区の住環境形成に大 きなインパクトを与えていることを指摘している。

これらの研究成果を踏まえつつ, 本研究は, 市街地住環境に及ぼ すマンションの影響と事業におけるマンションの計画決定メカニズ ムの分析を通して, 個別中高層マンション建設による市街地住環境 整備上の方策を探るものである。

\section{2. 調查概要}

\section{2-1 調查方法と時期}

本研究における調査は，i 現地調查，ii）ヒアリング調查からな る。本研究で対象とするマンションは民間事業者が開発した 3 階建 以上の共同住宅とする。

\section{（1）現地調查}

兵庫県西宮市から 2 地区, 神戸市から 2 地区計 4 地区の市街地特 性が異なる調查対象地区を選出した。現地調査では, 住宅地図(ゼン リン)をもとに作成したマンションごとのフィールドマップ(縮尺 1/200)に, マンション配置図, 各階平面図及び周辺建物の屋根伏, 階数，用途を記録し，測定可能な敷地辺長をレーザー距離計により 実測した。供給方式や開発事業者は現地でのヒアリング等によった。

西宮市 $\mathrm{K}$ 地区の調査は 2000 年 6 月, $\mathrm{Y}$ 地区は同 7 月に行い, 2001 年 6 月に両地区で追加調查を行った。神戸市 $\mathrm{F}$ 地区の調查は 2001 年 $11 \cdot 12$ 月, $\mathrm{T}$ 地区は 2002 年 6 月に行った。

(2) ヒアリング調查

ヒアリング調查は, まちづくり協議会役員を対象に行った。ヒア リング項目は，i）個別マンションについて，ii）地区計画·まちづく り協定の経緯, iii)その他, である。ヒアリングは西宮市の K 地区, $\mathrm{Y}$ 地区及び神戸市の $\mathrm{F}$ 地区において各地区 2 〜 回ずつ実施した。

\section{2-2 調查対象地区}

図 1 は, 調査対象地区位置図である。調査対象地区は都市計画事 業等の復興事業の対象になっていない。K 地区(9.4ha)，Y 地区 (17.7ha), F 地区(20.1ha)ではまち つくり協議会が結成されているが, $\mathrm{T}$ 地区(3.3ha)では結成されてお らず，今のところ予定もない。ま た, $\mathrm{K}$ 地区・Y 地区では地区計画が 決定されており，F 地区ではまち づくり協定が締結されている。

\section{3. 規制等の実態}

マンション建物に係る規制等を，行政(西宮市・神戸市)の対応に よるものと調查対象地区の地元住民の対応によるものからみる。 3-1 行政の対応

主に高さ制限に係る市条例，指導要網等の概要を整理する注3)。

1）西宮市：マンション問題への対応は早く,「中高層建築物の建 築に関する指導要綱」が 1973 年に施行され, これが「西宮市環境保 全条例」（1997 年）で条例化されている。ここでは, 商業系用途地 域以外で中高層建物(高さ $10 \mathrm{~m}$ を超えるもの又は階数 4 以上)を建築 する場合, 敷地面積が $500 \mathrm{~m}^{2}$ 以上必要とされ, $500 \mathrm{~m}^{2}$ 未満敷地が多 い住宅市街地の中高層化に一定の秩序を与えている。

震災後にはマンション紛争の頻発に対して, 1998 年 4 月に既存 不適格の発生にもかかわらず，高度地区を強化している。

2）神戸市: 高度地区の北側斜線以外では西宮市のような独自の高 さ制限はなく，震災後の規制強化もみられない。

\section{3-2 地元住民の対応}

まちづくり協議会を有する $\mathrm{K}$ 地区， $\mathrm{Y}$ 地区， F 地区における地元 住民の対応を地区ごとにみる。

1） $\mathrm{K}$ 地区：1988 年に $\mathrm{K}$ 町自治会によって自主協定が策定されて いる。その内容は原則として地区内で 4 階建以上の建物及びワンル ームマンションの建設を認めないというものであった。震災後のマ ンションの急增に対応するため, $\mathrm{K}$ 町自治会を母体として 1997 年 にまちづくり協議会が発足し, 2000 年に地区計画を定めた。地区計 画では, 市条例の中高層建物の建築基淮に係らない $500 \mathrm{~m}^{2}$ 以上の敷 地に対しても住居系地域 $12 \mathrm{~m}$, 近商地域 $20 \mathrm{~m}$ という高さ制限を設 けるなど，他の 3 地区に比して厳しい規制を設けた。

2) $\mathrm{Y}$ 地区 : 震災前後の近商地域の相次ぐ高層マンション化をきっ かけに, 近隣の 12 の自治会を母体に 1995 年にまちづくり協議会が 発足し, 1998 年に地区計画を定めた。 $\mathrm{K}$ 地区同様に $500 \mathrm{~m}^{2}$ 以上の 敷地に対して $12 \sim 30 \mathrm{~m}$ という高さ制限を設けた。

3） F 地区：1990 年に F 地区連合自治会を母体にまちづくり協議 会が発足し, 1993 年にまちづくり構想作成, 1995 年にまちづくり 協定を締結した。ただし, 高さ制限にかかわる条項は盛り込まれて いない。今のところ地区計画への移行は考えられていない。

\section{4. 調查対象地区の市街地変容とマンション化}

調查対象地区の市街地変容とマンション化の実態を分析する。分 析には 1978 年版・1994 年版・2000 年版の住宅地図(ゼンリン)及び住 宅地図発行年に最も近い各自治体発行の市街地図(1/2500)を用いた。 1970 年代後半(1978 年版)は, 各街区に建物が建ち並ぶことにより 4 地区全てにおいて市街地化がほぼ完了した年代であり，1994 年版は 震災直前, 2000 年版は調查研究開始時点での最新版である。

\section{4-1 調查対象地区の現況}

図 2 は建物の位置を住宅形式別に表したものであり，表 1 は住宅 形式の構成を棟数比と戸数比で集計したものである。

各調查対象地区の用途地域指定は，第 1 種中高層住居専用地域. 第 1 種住居地域(以下併せて住居系地域と省略する)及び近隣商業地 域(以下近商地域と省略する)であり，指定容積率は $200 \sim 300 \%$ であ る。各地区とも住居系地域が主で, 近商地域は幹線道路沿道の指定 である。 
住宅形式の構成を棟数比でみると,「民間マンション」の割合が最 も高いのは T 地区の $34 \%$ であり， F 地区が $16 \%, \mathrm{Y}$ 地区・K 地区 が $10 \%$ 前後となる。「民間マンション」の割合を戸数比でみると, $45 \%$ 86\%となる。戸数比ではいずれの調查対象地区も概ね半数以 上は民間マンションである。

\section{4-2 街区敷地割りとその变遷}

表 2 は調査対象地区の市街地化の概要を一覧表にしたものである。 （1）基盤整備

調査対象地区 4 地区は戦前に基盤整備されている。 $\mathrm{K}$ 地区・ $\mathrm{F}$ 地区

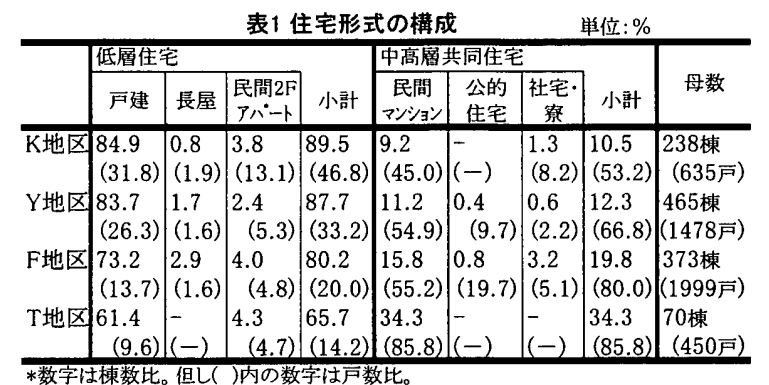
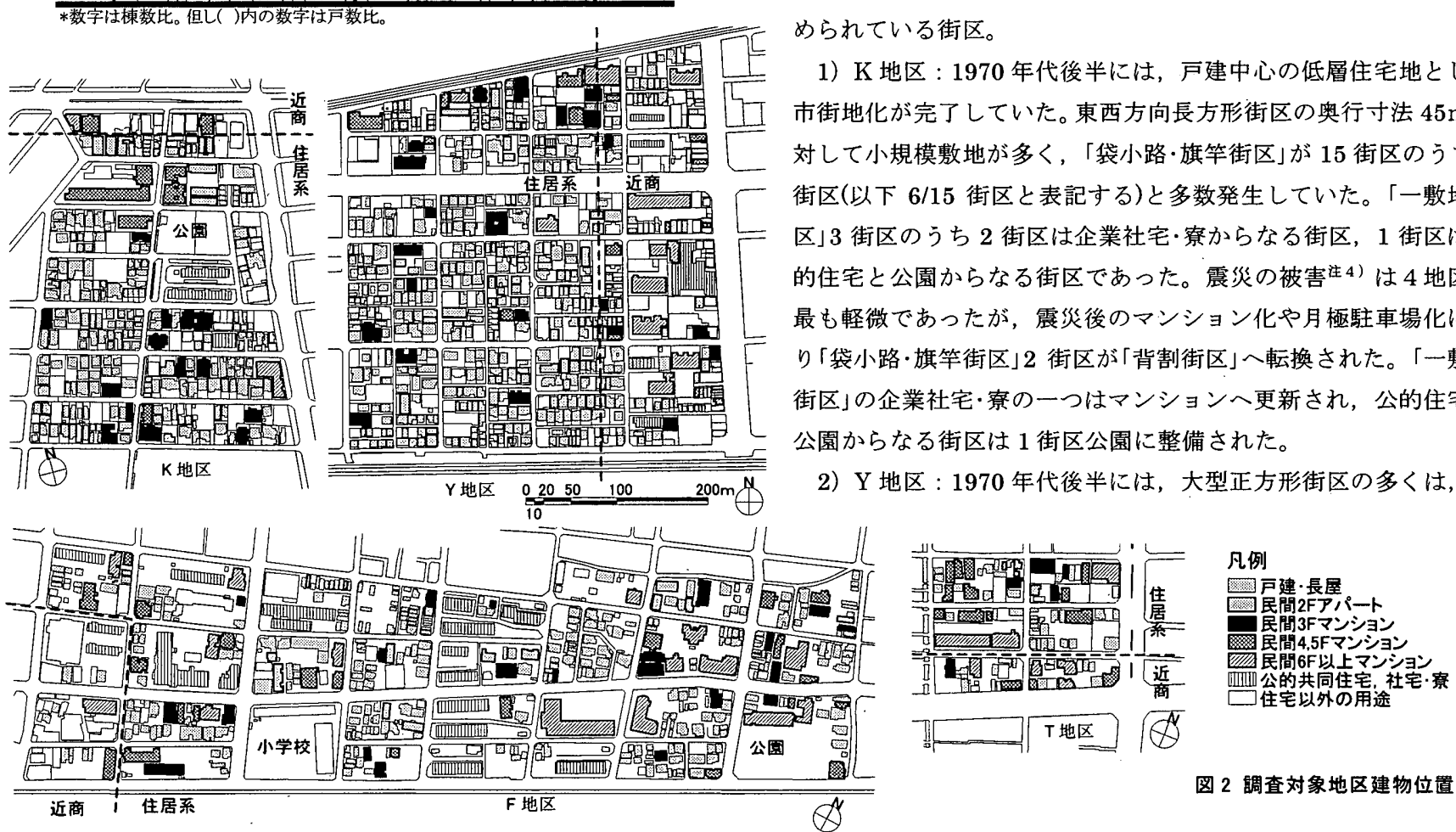
街区(以下 6/15 街区と表記する)と多数発生していた。「一敷地街 区」3 街区のうち 2 街区は企業社宅·寮からなる街区，1 街区は公 的住宅と公園からなる街区であった。震災の被害注4) は 4 地区で 最も軽微であったが，震災後のマンション化や月極駐車場化によ り「袋小路·旗竿街区 $」 2$ 街区が「背割街区」へ転換された。「一敷地 街区」の企業社宅·寮の一つはマンションへ更新され，公的住宅と 公園からなる街区は 1 街区公園に整備された。

2）Y 地区：1970 年代後半には, 大型正方形街区の多くは, 戸

図 2 調査対象地区建物位置図

表2 調查対象地区の市街地化の概要

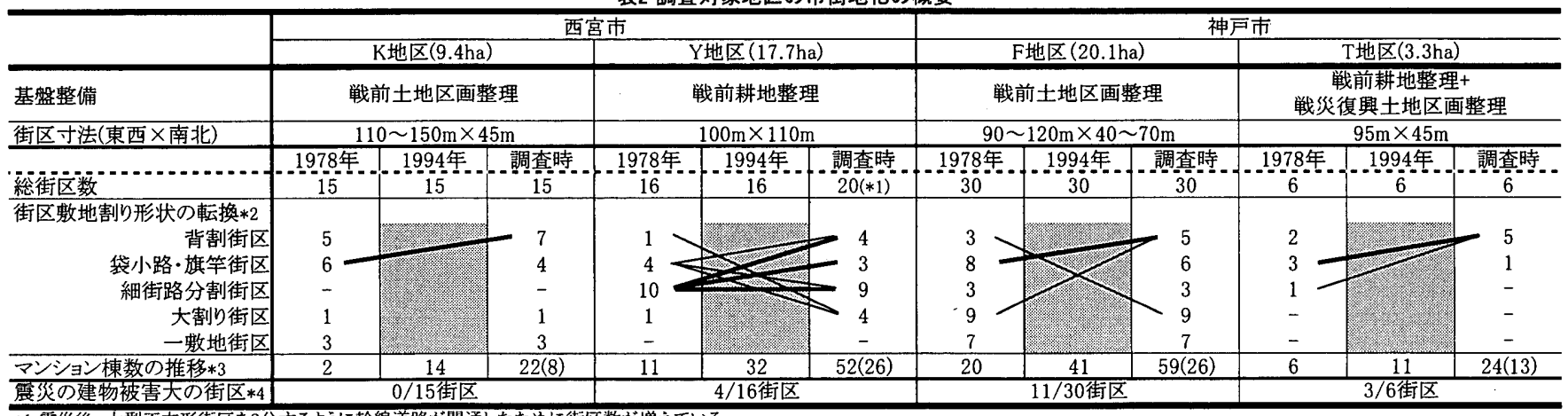

*1 售災後, 大型正方形街区を2分するように幹線道路が開通したために街区数が增えている。

*21978年から調查時の間で街区数地割り形状に変化があったものは，その転換を直線で結ぶことにより表現している。細線は該当する転換が1街区, 太線は2街区あったことを表す。

*3( )内の数字は震災後に竣エしたマンションの棟数。内数。

*4 街区内の半数以上の建物が「全壊又は大破」の街区数。各建物の被災度評価は「阪神·淡路大震災被害実態緊急調查被災度別建物分布状況図」日本都市計画学会関西支部・日本建築学会近畿 支部都市計画部会, 1995.3)を用いた。 
建·長屋の敷地規模に合わせて細街路で再分割された「細街路分割街 区」(10/16 街区)であった。震災で半数以上の建物が全壊又は大破と なった街区数は 4/16 街区であった。震災後は，地区を東西に横断す る広幅員道路の開通による街区の分割・形状変化により,さらにマン ション化や月極駐車場化により「背割街区」が增えた。「大割街区」の 増加は大規模マンションへの更新によるものである。

3） F 地区 : 1970 年代後半には， $2 \mathrm{~F} ア$ パート・長屋を多く含む低 層住宅と低層公的住宅群により, 各街区は「袋小路・旗竿街区」(8/30 街区),「大割街区」(9/30 街区),「一敷地街区」(7/30 街区)など様々な 形状の敷地割りがなされていた。震災で半数以上の建物が全壊又は 大破となった街区数は 11/30 街区であった。震災後は, マンション 化や月極駐車場化等により，「袋小路·旗竿街区」 2 街区が「背割街区」 に転換された。「大割街区」「一敷地街区」の多くを占める公的住宅は 中高層化されている。

4） $\mathrm{T}$ 地区: 1970 年代後半には, 半数の街区が $2 \mathrm{~F}$ アパート・長屋 を含む低層建物の裹敷地をもつ「袋小路・旗竿街区」(3/6 街区)であっ た。震災で半数以上の建物が全壊又は大破となった街区数は $3 / 6$ 街 区であった。震災後のマンション化や月極駐車場化により「袋小路・ 旗竿街区」は 1 街区に減った。

4 地区とも市街地化の過程で裏敷地, 旗竿敷地等が多く発生して いたが, 震災後, マンション化や月極駐車場化などにより，その幾 つかが統合された。

\section{4-3 マンション化の経緯}

\section{(1) 棟数の推移}

震災の直前には各地区とも住宅地として成熟段階に達しており， マンション化も進行しつつあった。1978 年と 1994 年のマンション 棟数を比較すると, $\mathrm{K}$ 地区 2 棟 $\rightarrow 14$ 棟, $\mathrm{Y}$ 地区 11 棟 $\rightarrow 32$ 棟, $\mathrm{F}$ 地 区 20 棟 $\rightarrow 41$ 棟, $\mathrm{T}$ 地区 6 棟 $\rightarrow 11$ 槙と各地区で大幅に増加していた。

震災によって倒壊したマンション及び震災後に取り壊されたマ ンションは, $\mathrm{Y}$ 地区(6/32 棟)及び $\mathrm{F}$ 地区(8/41 棟)において多く, K 地区及びT地区ではみられなかった。また，取壊しマンションのう ち Y 地区では 2 棟, $\mathrm{F}$ 地区では 3 棟が戸建や $2 \mathrm{~F}$ アパートのマンシ ヨン以外の住宅形式で再建されている。

震災直前の 1994 年と調査時のマンション棟数を比較すると, $\mathrm{K}$ 地区 14 棟 $\rightarrow 22$ 棟, $\mathrm{Y}$ 地区 32 棟 $\rightarrow 52$ 棟, $\mathrm{F}$ 地区 41 棟 $\rightarrow 59$ 棟, $\mathrm{T}$ 地区 11 棟 $\rightarrow 24$ 棟である。被害が大きかった地区で震災後のマンシ

表3 竣工時期別マンション従前用途

\begin{tabular}{|c|c|c|c|c|c|c|c|c|c|c|c|c|c|c|c|c|}
\hline 數地 & & 一敨 & 地 $* 2$ & & & & 複数致 & 建物(敬) & 地)統合 & & & & & & & \\
\hline 焚工時期 & $\begin{array}{l}\text { 分 } \\
\text { 割 } \\
* 1\end{array}$ & $\begin{array}{l}\text { 低畨 } \\
\text { 住宅 }\end{array}$ & \begin{tabular}{|c|} 
中高 \\
層 \\
共同 \\
住宅 \\
\end{tabular} & $\mid \begin{array}{c}\text { 事業 } \\
\text { 所 }\end{array}$ & \begin{tabular}{|l|} 
駐車 \\
場. \\
空地
\end{tabular} & 小計 & $\begin{array}{l}\text { 低屡 } \\
\text { 住宅 }\end{array}$ & \begin{tabular}{|c} 
低層住 \\
宅+駐 \\
車場· \\
空地
\end{tabular} & $\begin{array}{c}\text { 低層住 } \\
\text { 宅+ } \\
\text { 事業所 }\end{array}$ & \begin{tabular}{c|} 
低層+ \\
中高層 \\
共同 \\
住宅
\end{tabular} & \begin{tabular}{|c|} 
中高 \\
層 \\
共同 \\
住宅 \\
\end{tabular} & $\begin{array}{c}\text { 整業 } \\
\text { 所 }\end{array}$ & $\begin{array}{l}\text { 事業所 } \\
\text { +駐車 } \\
\text { 場. } \\
\text { 空地 }\end{array}$ & $\begin{array}{l}\text { 駐車 } \\
\text { 場- } \\
\text { 空地 }\end{array}$ & 小計 & 合計 \\
\hline K地区 & - & 6 & 1 & - & 8 & 15 & $3(2)$ & - & 1 & - & $=$ & 1 & E & - & $5(2)$ & 20 \\
\hline 1995年～現在 & - & - & 1 & - & 4 & 5 & $3(2)$ & - & - & - & - & - & - & - & $3(2)$ & 8 \\
\hline 1979 1994年 & - & 6 & - & - & 4 & 10 & - & - & 1 & - & - & 1 & - & - & $2(-)$ & 12 \\
\hline Y地区 & 3 & 13 & 3 & 2 & 13 & 31 & $3(1)$ & $4(3)$ & $1(1)$ & 1 & - & - & $1(1)$ & 1 & $11(6)$ & 45 \\
\hline 1995年～現在 & 3 & $\overline{5}$ & 3 & 1 & 5 & 14 & 3(1) & $3(2)$ & - & 1 & - & - & 1(1) & 1 & $9(4)$ & 26 \\
\hline 1979～1994年 & - & 8 & - & 1 & 8 & 17 & - & 1(1) & 1(1) & - & - & - & 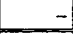 & - & 2(2) & 19 \\
\hline F地区 & 4 & 14 & 3 & 5 & 5 & 27 & $8(4)$ & $3(2)$ & $2(2)$ & - & $2(1)$ & - & $1(1)$ & - & $16(10)$ & 47 \\
\hline 1995年～現在 & 1 & 7 & 3 & 2 & 2 & 14 & $4(3)$ & $2(1)$ & $2(2)$ & - & $2(1)$ & - & 1(1) & - & $11(8)$ & 26 \\
\hline 1979～1994年 & 3 & 7 & - & 3 & 3 & 13 & 4(1) & $1(1)$ & - & - & - & - & - & - & $5(2)$ & 21 \\
\hline T地区 & 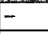 & 3 & - & 2 & 4 & 9 & $4(4)$ & $2(1)$ & 1 & - & - & $1(1)$ & - & 1 & $9(6)$ & 18 \\
\hline 1995年 & - & 2 & - & 1. & 2 & $\overline{5}$ & $3(3)$ & $2(1)$ & 7 & - & - & $1(1)$ & - & 1 & $8(5)$ & 13 \\
\hline $1979 \sim 1$ & & & & 1 & & & 1(1) & & & & & & & & 1(1) & \\
\hline
\end{tabular}

* 現存するマンションを対象とする。取壊し・更新により見存しないものは対像外とする。1978年以前のマンションの従前用途は未調查 のため合㖕には含まれていない。

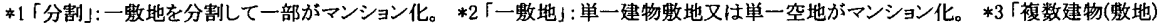

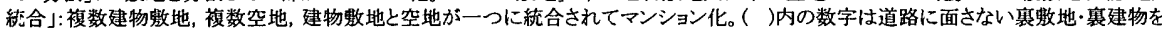
含む事例数。内数。
ョンが多い。一方, 被害の小さかった地区でも従来に比べてマンシ ヨン化が加速している。

（2）竣工時期別従前用途

表 3 は現存マンションの従前用途を竣工時期別に集計したもので ある。1978 年以前に䇋エしているものは対象外である。

震災前竣工事例は，いずれの地区においても「一敷地」の「低層住 宅」や駐車場・空地」が主である。早くからマンション化が進行して いた F 地区では「複数建物(敷地)統合」が 5 例と他に比してやや多く， 「分割」によるマンション化もわずかにみられる。

震災後竣工事例は, いずれの地区においても震災前より「複数建 物(敷地)統合」が増えており、「低層住宅」又は「月極駐車場」を含んだ ものが多い。「複数建物(敷地)統合」は震災の被害が大きかった地区 で多く, 特に T 地区では震災後䇋工事例 13 例中 8 例が該当する。 $\mathrm{F}$ 地区では複数棟が建つ「中高層共同住宅」敷地の更新が 2 例あり(1 例 はマンション, 1 例は社宅)，いずれも階数は従前より增えている。 また各地区において半数程度あるいは半数以上の事例が道路に面さ ない「裹敷地·裹建物」を含んだマンション化である。「一敷地」での更 新は，震災前と同様「低層住宅」又は「駐車場・空地」が多いが，震災の 被害が軽微だった $\mathrm{K}$ 地区では「低層住宅」はみられない。Y 地区，F 地区では「中高層共同住宅」が 3 例ずつあり，いずれもマンションの 更新である。K 地区の 1 例は企業社員寮の更新である。更新後の建 物階数は従前と同じか増えている。「分割」によるマンション化は $\mathrm{Y}$ 地区と $\mathrm{F}$ 地区で少数みられる。

\section{（3）竣工時期別建物階数}

表 4 は現存マンションの建物階数及び敷地規模を䇋工時期別に集 計したものである。震災前竣工事例は，西宮市の 2 地区では「3 階」 が主であり，「4,5 階」が続く。「6 階以上小は Y 地区の 3 例のみであ る。神戸市の 2 地区では「4,5階」が主であり，「3 階」が続く。T 地区 には「6 階以上」はないが, F 地区では 1978 年以前の 2 棟を含めて, 震災前が 7 棟ある。

震災後竣工事例は, 西宮市の 2 地区では「3 階」が多いが, 「4,5 階」 や「6 階以上」も増えている。 $\mathrm{K}$ 地区の「6階以上」の 2 例は幹線道路 沿道に立地する。Y 地区の「6 階以上」9 例のうち 8 例は近商地域に 集中している。神戸市の $\mathrm{F}$ 地区の階数の分布はY 地区と似ているが,

\begin{tabular}{|c|c|c|c|c|c|c|c|c|}
\hline \multicolumn{5}{|c|}{ 豆4 竣工時期別階数と褡地規模 } & & \multicolumn{3}{|c|}{ 単位:事例数 } \\
\hline & & 物階 & & & 放地 & 地规㒻枆 & 莫*1 & \\
\hline 䇋工时 & $3 \mathrm{~F}$ & $\begin{array}{c}4 \mathrm{~F} \\
\dot{5 F}\end{array}$ & $\begin{array}{l}6 \mathrm{~F} \\
\text { 以 } \\
\text { 上 }\end{array}$ & 計 & $\begin{array}{l}\text { 小 } \\
\text { 規 } \\
\text { 模 }\end{array}$ & $\begin{array}{c}\text { 中 } \\
\text { 規 } \\
\text { 模 }\end{array}$ & $\begin{array}{l}\text { 大 } \\
\text { 規 } \\
\text { 模 }\end{array}$ & 計 \\
\hline K地区 & 14 & 6 & 2 & 22 & 9 & 8 & 5 & 22 \\
\hline 1995年～現在 & 4 & 2 & 2 & 8 & 3 & 3 & 2 & 8 \\
\hline 1979～1994年 & 10 & 2 & - & 12 & 5 & 5 & 2 & 12 \\
\hline 1978年以前 & - & 2 & - & 2 & 1 & - & 1 & 2 \\
\hline Y地区 & 26 & 14 & 12 & 52 & 23 & 16 & 13 & 52 \\
\hline 1995年～現在 & 11 & 6 & 9 & 26 & 8 & 8 & 10 & 26 \\
\hline 1979～1994年 & 11 & 5 & 3 & 19 & 11 & 7 & 1 & 19 \\
\hline 1978年以前 & 4 & 3 & - & 7 & 4 & 1 & 2 & 7 \\
\hline F地区 & 21 & 23 & 15 & 59 & 19 & 19 & 21 & 59 \\
\hline 1995年～現在 & 10 & 8 & 8 & 26 & 8 & 9 & $\overline{9}$ & 26 \\
\hline 1979～1994年 & 8 & 8 & 5 & 21 & 7 & 7 & 7 & 21 \\
\hline 1978年以前 & 3 & 7 & 2 & 12 & 4 & 3 & 5 & 12 \\
\hline T地区 & 4 & 14 & 6 & 2 & 12 & 9 & 3 & 24 \\
\hline 1995年～現在 & 2 & 5 & 6 & 13 & 4 & 6 & 3 & 13 \\
\hline 1979～1994年 & - & 5 & - & 5 & 3 & 2 & - & 5 \\
\hline 1978年以前 & 2 & 4 & - & 6 & 5 & 1 & 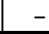 & 6 \\
\hline
\end{tabular}


$\mathrm{F}$ 地区では「6 階以上」も含めて全てのマンションが住居系地域に建 てられている。T 地区では「3 階」は少数で, 「4,5階」及び「6 階以上」 が多く, 近商地域での増加が著しい。

（4）立工時期別敷地規模

敷地規模注 5) は i ) $500 \mathrm{~m}^{2}$ 以上 (以下, 大規模), ii ) $500 \mathrm{~m}^{2}$ 未満 300

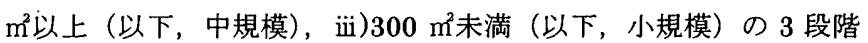
に区分した。敷地面積 $500 \mathrm{~m}^{2}$ 以上」は，西宮市・神戸市において開 発事業とみなされる面積であり，低層建物を主とした住宅市街地で は相対的に規模の大きな敷地である。「敷地面積 $300 \mathrm{~m}^{2}$ 未満」は, 西宮市において駐車場設置緩和に係る面積であり，概ね戸建住宅 1 敷地に相当する規模である。

震災前竣工事例は, $\mathrm{K}$ 地区・Y 地区・T 地区では小規模が最も多く， 中規模が続き，大規模は少数である。特に $\mathrm{T}$ 地区では大規模は存在 しない。マンション化初期から 6 階建以上のマンションが建てられ ていた F 地区のみは，小規模(11 例)・中規模(10 例) ·大規模(12 例) それぞれが同程度である。

震災後竣工事例は， $\mathrm{F}$ 地区では震災前と同様に小規模(8 例) -中規 模(9 例)・大規模(9 例)それぞれが同程度である。Y 地区では大規模が 急增し 10 例と最も多くなっている。大規模がなかった $\mathrm{T}$ 地区でも 大規模が 3 例みられるようになり，震災の被害が軽微だった $\mathrm{K}$ 地区 においても大規模が 2 例建てられた。

\section{5. マンション建築計画の基本事項}

調査対象地区に立地するマンションの計画内容の基本事項（建物 高さ、容積率）と敷地規模，供給方式等の実態及び法規制との関係 を分析する。

\section{5-1 敷地規模と建物高さ}

表 5 は用途地域, 敷地規模段階別に建物階数を 3 段階に区分して 集計したものである。総延床面積を総建築面積で除した平均階数も 算出した。4 地区全体でみると, 住居系地域では,「6 階以上」は大 規模に限定され，小・中規模ではほとんどが「3 階」か「4,5階」である。 近商地域では，大規模はすべて「6 階以上」，小.中規模でも「6 階以 上」がみられる。

地区別にみる。住居系地域の小・中規模においては「西宮市環境保 全条例」による高さ制限のため，西宮市の 2 地区ではほとんどが「3 階」であるが, 高さ制限のない神戸市の 2 地区では「4,5 階」が多い。 大規模でも西宮市の 2 地区では「4,5 階」が中心なのに対し，神戸市 の 2 地区では「6 階以上」が多い。西宮市の 2 地区では「6 階以上」 が建設され出す前に, 住居系地域の広い範囲で地区計画による「 $12 \mathrm{~m}$ 以下」の高さ制限を設けたので，これらの範囲では今後「6 階以上」 が建設されることはない。平均階数をみると，住居系地域では西宮 市の 2 地区は 4 階未満であるのに対して神戸市の 2 地区では 4 階以 上となる。近商地域では大規模「6 階以上」の蓄積が多いY 地区で 6.6 階と最も高くなる。

\section{5-2 供給方式と開発事業者}

（1）供給方式

表 6 は敷地規模段階別に供給方式を示したものである。4 地区全 157 例のうち 41 例が「分譲」, 116 例が「賃貸」であり，小.中規模で は「賃貸」の割合が高く,大規模では「賃貸」と「分譲」が同程度である。 地区別でみると，西宮市の 2 地区は神戸市の 2 地区に比して「分

譲」の割合が高い。

(2) 開発事業者

表 7 は，開発事業者を「個人」と「法人」に分類し，供給方式ごとに 集計したものである。全 157 例のうち「法人」 42 例，「個人」 109 例， 「不明」が 6 例ある。開発事業者が「個人」の事例は 9 割以上が「貨貸」 であり，まちづくり協議会役員へのヒアリング調査によれば，相続 時の節税対策や老後の安定収入確保の目的で経営される場合が多い。

表5 用途地域·敷地規模と建物階数単位:或例数

\begin{tabular}{|c|c|c|c|c|c|c|}
\hline & & 3階 & 4,5階 & 6階以上 & 合計 & 平均階数 \\
\hline K地区 & $\begin{array}{r}\text { 住居系地域 } \\
\text { 大規模 } \\
\text { 中規模 } \\
\text { 小規模 }\end{array}$ & \begin{tabular}{ll|}
14 & \\
& 1 \\
& 6 \\
& 7 \\
\end{tabular} & $\begin{array}{l}3 \\
- \\
1\end{array}$ & $\begin{array}{ll}1 & \\
& 1 \\
& - \\
& -\end{array}$ & \begin{tabular}{ll|}
19 & \\
& 5 \\
& 6 \\
& 8 \\
\end{tabular} & $(3.2)$ \\
\hline & $\begin{array}{r}\text { 近商地域 } \\
\text { 大規模 } \\
\text { 中規模 } \\
\text { 小規模 }\end{array}$ & $\begin{array}{l}- \\
- \\
-\end{array}$ & 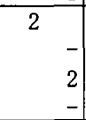 & - & \begin{tabular}{|r|r|}
3 & \\
& - \\
& 2 \\
& 1 \\
\end{tabular} & $(5.2)$ \\
\hline Y地区 & $\begin{array}{r}\text { 住居系地域 } \\
\text { 大規模 } \\
\text { 中規模 } \\
\text { 小規模 }\end{array}$ & \begin{tabular}{rr|}
19 & \\
& 2 \\
11 \\
\\
6
\end{tabular} & \begin{tabular}{ll|}
6 & \\
& 3 \\
& 1 \\
& 2 \\
\end{tabular} & $\begin{array}{ll}2 & \\
& 1 \\
& 1 \\
& -\end{array}$ & \begin{tabular}{rr|}
27 & 6 \\
& 13 \\
& 8
\end{tabular} & (3.6) \\
\hline & $\begin{array}{r}\text { 近商地域 } \\
\text { 大規模 } \\
\text { 中規模 } \\
\text { 小規模 }\end{array}$ & 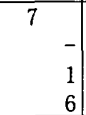 & $\begin{array}{l}- \\
1 \\
7\end{array}$ & \begin{tabular}{rr|}
10 & \\
& 7 \\
& 1 \\
& 2
\end{tabular} & \begin{tabular}{rr|}
25 & \\
& 7 \\
& 3 \\
& 15 \\
\end{tabular} & $(6.6)$ \\
\hline F地区 & $\begin{array}{r}\text { 住居系地域 } \\
\text { 大規模 } \\
\text { 中規模 } \\
\text { 小規模 }\end{array}$ & \begin{tabular}{rr|}
21 & 3 \\
8 \\
10
\end{tabular} & 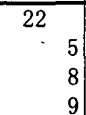 & $\begin{array}{r}14 \\
13 \\
1 \\
-\end{array}$ & \begin{tabular}{|l|}
57 \\
21 \\
17 \\
19
\end{tabular} & $(4.1)$ \\
\hline & $\begin{array}{r}\text { 近商地域 } \\
\text { 大規模 } \\
\text { 中規模 } \\
\text { 小規模 }\end{array}$ & $\begin{array}{r}- \\
- \\
- \\
\end{array}$ & $\begin{array}{l}- \\
1 \\
-\end{array}$ & $\begin{array}{ll}1 & \\
& 1 \\
& - \\
& - \\
\end{array}$ & \begin{tabular}{ll|}
2 & \\
& 1 \\
& 1 \\
& - \\
\end{tabular} & $(4.8)$ \\
\hline T地区 & $\begin{array}{r}\text { 住居系地域 } \\
\text { 大規模 } \\
\text { 中規模 } \\
\text { 小規模 }\end{array}$ & 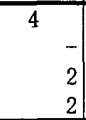 & 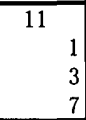 & $\begin{array}{ll}2 \\
2 \\
- \\
-\end{array}$ & 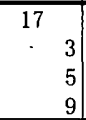 & $(4.0)$ \\
\hline & $\begin{array}{r}\text { 近商地域 } \\
\text { 大規模 } \\
\text { 中規模 } \\
\text { 小規模 }\end{array}$ & $\begin{array}{r}- \\
- \\
- \\
-\end{array}$ & $\begin{array}{l}- \\
- \\
3\end{array}$ & $\begin{array}{l}- \\
4 \\
-\end{array}$ & \begin{tabular}{rr|}
7 & \\
& 4 \\
& 3 \\
\end{tabular} & $(5.0)$ \\
\hline 4地区計 & $\begin{array}{r}\text { 住居系地域 } \\
\text { 大規模 } \\
\text { 中規模 } \\
\text { 小規模 }\end{array}$ & $\begin{array}{r}58 \\
6 \\
27 \\
25\end{array}$ & $\begin{array}{r}43 \\
12 \\
12 \\
19\end{array}$ & $\begin{array}{r}19 \\
17 \\
2 \\
-\end{array}$ & $\begin{array}{r}120 \\
35 \\
4.1 \\
44\end{array}$ & $(3.8)$ \\
\hline & $\begin{array}{r}\text { 近商地域 } \\
\text { 大規模 } \\
\text { 中規模 } \\
\text { 小規模 }\end{array}$ & $\begin{array}{l}- \\
1 \\
6\end{array}$ & 14 & 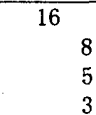 & $\begin{array}{rr}37 & \\
& 8 \\
& 10 \\
19 \\
19\end{array}$ & $(6.1)$ \\
\hline & 合計 & 65 & 57 & 35 & 157 & $(4.3)$ \\
\hline
\end{tabular}

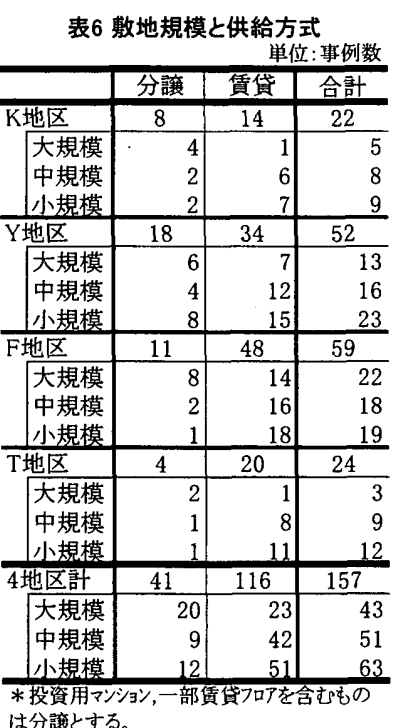

は分僙とする。
表7 開発事業者と供給形式

\begin{tabular}{l}
\hline \\
\hline
\end{tabular}

事例数。内数。 
開発事業者が「法人」の事例は約 8 割が「分譲」である。地区別でみる と神戸市の 2 地区の「個人」事業者は地区内居住者が多い。

\section{5-3 マンション建物の容䅣消化}

ここでは，指定容積率に対する事例ごとの容積率の割合である容 積消化率を用いて，各事例の容積消化の程度を分析する。容積消化 率 $90 \%$ 以上を概ね指定容積率を消化している事例と判断している。 容積消化率 $90 \%$ 未満は容積未消化事例と判断し，3 段階に分けてい る。

調查対象地区における指定容積率は，住居系地域においては殆ん どの範囲が $200 \%$ の指定であるが， T 地区の 1 例のみは $300 \%$ 指定 の籁囲に位置する。近商地域は全て $300 \%$ の指定である。

（1）敷地規模と容積消化率

まず，敷地規模と容積消化率の関係をみる。表 8 は用途地域，敷 地規模段階別に容積消化率を集計したものである。

全 157 例のうち容積消化率「 $90 \%$ 以上」が 74 例で最も多い。用途 地域別でみると近商地域の方が「90\%以上」の割合が高い。規模別で みると, 容積消化率が高いのは大規模, 小規模, 中規模の順である。

地区別にみると，住居系地域に扔ける西宮市の 2 地区と神戸市の 2 地区の差が顕著である。西宮市の 2 地区では小規模において容積 消化率「 $90 \%$ 以上」が最も多く，大規模，中規模においては「80\%以 上 $90 \%$ 末満」あるいはそれ以下が最も多くなっている。神戸市の 2

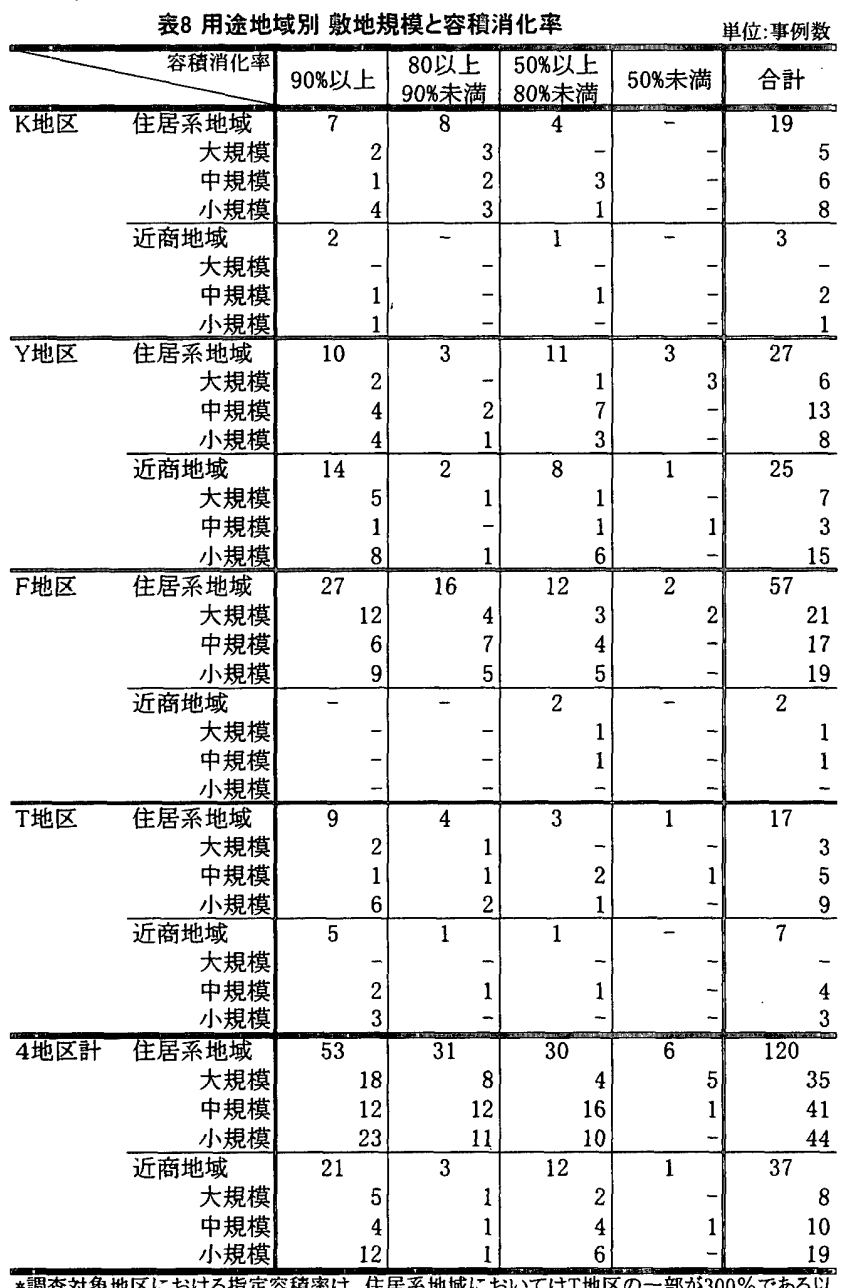

\#調査対象地区における指定容䅡率は，住居紊地域においてはT地区の一部が $300 \%$ あ゙ある 外恃全て $200 \%$ である。300\%の指定部分に立地するマンションは1例のみである。近商地域は 全て $300 \%$ の指定である。
地区では小規模だけでなく大規模においても「 $90 \%$ 以上」が最も多 くなる。中規模は西宮市の 2 地区同様容積未消化の事例が多い。

（2）供給方式と容積消化率

表 9 は供給方式別に容積消化率を集計したものである。4 地区全 体では，「賃貸」において容積消化率「90\%以上」の事例が約 4 割であ るが，「分譲」では 7 割近い。事業収支上，「分譲」では容積消化が優 先されるが,「賃貸」では必ずしもそうでないということが表れてい る。

地区別でみると，「分譲」については西宮市の 2 地区においては $\lceil 80 \%$ 以上 $90 \%$ 未満」あるいは「50\%以上 $80 \%$ 未満」の容積未消化の 事例が神戸市の 2 地区に比して多い。西宮市の 2 地区においては, 高度地区の北側斜線や地区計画等による高さなどの制限が神戸市の 2 地区に比して撖しいためと考えられる。賃貸」についてはY 地区, $\mathrm{F}$ 地区では容積未消化の事例が多く， T 地区で少ない。

\begin{tabular}{|c|c|c|c|c|c|c|}
\hline \multirow{2}{*}{\multicolumn{2}{|c|}{ 肖化率 }} & \multicolumn{3}{|c|}{ 表9 供給方式と容積消化率 } & \multicolumn{2}{|c|}{ 単位: 事例数 } \\
\hline & & 90\%以上 & $\begin{array}{l}80 \% \text { 以上 } \\
90 \% \text { 末渵 }\end{array}$ & $\begin{array}{l}50 \% \text { 以上 } \\
80 \% \text { 未渵 }\end{array}$ & $50 \%$ 未満 & 合計 \\
\hline \multirow[t]{3}{*}{ K地区 } & 分讓 & $\overline{3}$ & 3 & 2 & - & \\
\hline & 賃貸 & 6 & 5 & 3 & - & 14 \\
\hline & 合計 & 9 & 8 & 5 & - & 22 \\
\hline \multirow[t]{3}{*}{ Y地区 } & 分銮 & 11 & 2 & 5 & - & 18 \\
\hline & 穓貸 & 13 & 3 & 14 & 4 & 34 \\
\hline & 合計 & 24 & 5 & 19 & 4 & 52 \\
\hline \multirow{3}{*}{ F地区 } & 分䜇 & $\overline{9}$ & 1 & 1 & $\overline{-}$ & 11 \\
\hline & 賃貸 & 18 & 15 & 13 & 2 & 48 \\
\hline & 合計 & 27 & 16 & 14 & 2 & 59 \\
\hline \multirow[t]{3}{*}{ T地区 } & 分譲 & 4 & -1 & -1 & 7 & \\
\hline & 賃貸 & 10 & 5 & 4 & 1. & 20 \\
\hline & 合計 & 14 & 5 & 4 & 1 & 24 \\
\hline \multirow[t]{3}{*}{ 4地区計 } & 分箕 & 27 & 6 & 8 & - & 41 \\
\hline & 儥貸 & 47 & 28 & 34 & 7 & 116 \\
\hline & 合訪 & 74 & 34 & 42 & 7 & 157 \\
\hline
\end{tabular}

6. まとめ

以上の分析結果より，市街地変容・法規制及び敷地規模・供給方式 との関係で, 市街地立地の中高層マンションの実態をまとめる。

1）震災後のマンション化による街区敷地割りの変化

今回の調查対象地はいずれも土地区画整理事業等によって街区割 りがなされた地区である。ここでは，100m 角の大割りの正方形街 区はもちろん，奥行 40〜 50m 程度の通常の寸法の街区でも，市街 地変容過程で多くの裏敷地・裏建物が発生していだ。震災後は, こ れらを統合した大規模敷地マンションが多く建てられた。これによ って裹敷地·裏建物が解消し，市街地が整えられる面もあるが，これ らのマンションは許容容積率限度一杯に建てられるものが多く，そ の集積が街区の密度を飛躍的に高めることになる。マンションに対 する規制は個別敷地対応で行われているが，街区あるいは地区対応 の方策も必要なことが示唆される。

2）マンション化の加速と大規模敷地 $\cdot 6$ 階以上住棟の増加

被害が大きかった地区はもちろん, 軽微だった地区でも震災後に マンション化が加速した。震災後のマンションは $500 \mathrm{~m}^{2}$ 以上の大規 模敷地が増えており，現状で全事例数の 3 割弱に達している。これ らの多くは法人開発による分譲で，震災前には少なかった 6 階以上 住棟が多い。震災復興の需要を見込んだ法人の急激な進出が, 地区 に大きな変化を及ぼした。地元住民の地区計画策定などがこれに対 する一応の歯止めになっているが，規制は高さ制限等に限られてお り,マンションの計画で許容容積率の消化が目的化されるなかでは, 
空地の減少などの別の問題を生ずることになる。

これは，対処療法的な規制強化がマンションの建築計画を歪める 例であり，計画全体のバランスに配慮した法規制が求められる。

3）小.中規模事例の特徴と問題点

敷地面積 $500 \mathrm{~m}^{2}$ 未満の小.中規模事例は全事例数の 7 割強であり, 個人事業者の貸貸が多く，震災前後を通して継続的に蓄積されてき ている。建物高さをみると，高さ制限のある西宮市の 2 地区では 3 階建が主であるが，高さ制限のない神戸市の 2 地区では 4,5 階建も 多い。建物高さに関しては，西宮市の行政·住民の対応は，住居系地 域の低層市街地における中高層化を抑制する効果を示している。し かし，小規模事例では容積率が神戸市の 2 地区と同程度に高いにも かかわらず高さを抑えられているために，建詰まりの傾向を招いて いる面もある。これも規制による建築計画の歪みの一つである。

4）供給方式による計画決定メカニズムの差異

中高層マンションの実態は, 供給方式による差異も大きい。容積 未消化事例は分譲では少なく，賃貸で多い。賃貸マンションは，個 人地主が経営するものが多く，土地代が収支に含まれない。そのた め, 容積未消化でも可とする計画決定メカニズムが働く場合がある。 これは分譲マンションと対照的である。

マンションの建築計画決定のメカニズムは, 供給方式によって大 きく異なる。市街地住環境形成に対しては，この点に配慮した方策 が必要なことが示唆される。

\section{参考文献}

1）土井幸平, 杉山茂一, 小野英道, 中村仁, 徳尾野徹, 酒井沢栄: 低層既成市街 地に抒ける段階的, 部分的中高層化に向けた計画的研究, 住宅総合研究財団 研究年報 No.27, pp.89 100,2001.3

2）平山洋介，木山幸介: 被災市街地における住宅再建の実態分析，日本建築学 会計画系論文集 No.512, pp.205 211, 1998.10

3) 重村力他 2 名: 被災住宅市街地の再建過程の研究, 日本建築学会計画系論文 集 No.513, pp.219〜225, 1998.11

4）酒井沢栄, 土井幸平:震災後の中高層共同住宅増加に伴住環境形成上の課 題, 日本建築学会計画系論文集 No.526, pp209 214, 1999.12

5）岡絵里子, 鳴海邦碩: 大阪市街地におけるマンションの立地動向と形態に関寸 万研究, 日本都市計画学会学術研究論文集 No.34, pp667 672, 1999.10

6) 高見沢実: 指導要網等の運用過程に着目した小規模開発規制誘導方策の総 合化に関する考察，日本都市計画学会学術研究論文集 No.24, pp199 204, 1989.10

7）中西正彦他 2 名:建築物の空間構成・相隣関係からみた形態規制の評価，日本 都市計画学会学術研究論文集 No.29, pp. $247 \sim 252,1994.10$

8）佐々木誠, 花里俊廣: 新築分譲マンションにおける住戸定型化とその要因の分 析，日本建築学会計画系論文集 No.535, pp59 66, 2000.09

9）鈴木雅之，中西敏、服部岑生:東京都内の既成市街地における集合住宅の外 部空間, 日本建築学会計画系論文集 No.519, pp.123 130, 1999.5

10）井上誠他 4 名:民間分諼マンションのプログラシング・プロセスの実情, 日本建 築学会計画系論文集 No.519, pp.241 247, 1999.5

11）小浦久子, 岡絵里子:市街地更新における共同住宅形態の多様化に関する研 究, 日本都市計画学会学術研究論文集 No.37, pp.559 564, 2002.10

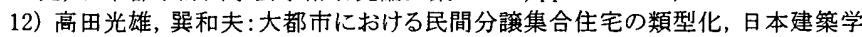
会計画系論文集 No.426,pp.83 90, 1991.8

注

1）参考文献 4 では，西宮市を対象として震災後のマンション立地とマンション紛争 の実態分析により，住環境形成に対する規制の限界を明らかにしている。

2）筆者らは，参考文献 1 において西宫市の被災地における中高層マンション化の 現状を概観し，都市計画の一般規制や地区住民による地区計画の有効性と限 界を明らかにしている。

3)「西宮の環境 昭和 53 年版〜平成 10 年版」(西宮市)及び「神戸市広報」(神戸 市の分析による。

4)「阪神・淡路大震災被害実態緊急調查 被災度別建物分布状況図」(日本都市 計画学会関西支部・日本建築学会近畿支部都市計画部会, 1995)老用いて，半 数以上の建物が「全壊又は大破」と判定されている街区数によって判断した。建 物の被災度評価は、外観の目視により 4 段階区分(「外観上の被害なし」「軽微な 損傷」「中程度の損傷「全壊又は大破」で評価されたものである。
5）事例の教地面積，建築面積，延床面積は，現地調查で収集したデータをもとに 作成した図面により計測した。

（2003年 3 月 3 日原稿受理， 2003 年 7 月 16 日採用決定） 